\title{
Antigen-specific Immunosuppression in Visceral Leishmaniasis Is Cell Mediated
}

Edgar M. Carvalho, Olivia Bacellar, Aldina Barral, Roberto Badaro, and Warren D. Johnson, Jr. Division of Immunology, Department of Medicine, University of Bahia, Salvador, Brazil; and Division of International Medicine, Department of Medicine, Cornell University Medical College, New York 10021

\section{Abstract}

Visceral leishmaniasis is associated with an antigen-specific immunosuppression during the acute disease. Patients become responsive to Leishmania antigen in both in vivo and in vitro assays after successful antimony therapy. The cell type involved in the suppression of lymphocyte reactivity to Leishmania antigen was studied by selective depletion of mononuclear cell (MNC) populations and in co-cultivation experiments. Adherent cells were depleted on plastic and by passage on nylon wool columns. High-avidity $\mathrm{Fc}^{+}$cells were depleted by adherence to BSA-anti-BSA complexes and OKT4 ${ }^{+}$and $\mathrm{OKT}^{+}$cells were depleted by treatment with monoclonal antibody (anti-OKT4 ${ }^{+}$and $\mathrm{OKT8}^{+}$) and complement. Depletion of MNC preparations of adherent cells, high-avidity $\mathrm{Fc}^{+}$cells, $\mathrm{OKT}_{4}{ }^{+}$cells and $\mathrm{OKT}_{8}{ }^{+}$cells failed to restore the lymphocyte reactivity to Leishmania antigen. Antimony therapy was associated with restoration of the proliferative responses of unseparated MNC (before treatment $460 \pm 76 \mathrm{cpm}$ and after treatment $4,293 \pm 1,442 \mathrm{cpm})$. Co-culture of frozen cells obtained before chemotherapy with autologous $\mathrm{MNC}$ obtained after treatment reduced the response of posttreatment cells to Leishmania antigen by $80 \%$. We conclude that the antigenic specific suppression of lymphocyte proliferation in visceral leishmaniasis is cell mediated.

\section{Introduction}

Visceral leishmaniasis is characterized by a depression of the cellular immune response to Leishmania antigen. Patients have negative intradermal skin tests $(1,2)$, absent lymphocyte blastogenesis (3-6), and decreased production of interleukin 2 and $\gamma$-interferon (7). They respond to mitogens in these assays and most patients also respond to recall antigens during the acute disease. After successful treatment leishmaniasis patients rapidly become responsive to Leishmania antigen (3).

The mechanism of the immunosuppression is unknown. It has been suggested that either serum factors $(4,8)$, decreased numbers of $T$ cells in peripheral blood $(7,9,10)$, absence of antigen-reactive cells in peripheral blood (11), or the presence

These studies were approved by the University of Bahia Human Rights Committee and by the Cornell University Medical College Committee on Human Rights in Research.

Address reprint requests to Dr. Edgar Carvalho, Laboratorio de Immunologia, Hospital Professor Edgar Santos, Rua Joao das Botas, s/n Canela, 40.000 Salvador, Bahia, Brazil.

Received for publication 27 February 1987 and in revised form 30 September 1988.

J. Clin. Invest.

(C) The American Society for Clinical Investigation, Inc. 0021-9738/89/03/0860/05 \$2.00

Volume 83, March 1989, 860-864 of suppressor cells might account for the diminished responsiveness. In the present study we were not able to restore the immune response to Leishmania antigen in a blastogenesis assay by depleting the mononuclear cell population of either macrophages, B cells, Fc receptor high-avidity cells, or OKT ${ }^{+}$ and $\mathrm{OKT}_{4}{ }^{+}$cells. However, we have determined that cells from unresponsive patients before therapy will abolish the ability of those same patients' cells to respond after therapy.

\section{Methods}

Patients. Patients with active visceral leishmaniasis admitted at the Federal University Hospital, in Salvador, Bahia, Brazil were studied. The patients had classic visceral leishmaniasis with fever, weight loss, hepatosplenomegaly, anemia, leukopenia, and hyperglobulinemia. The diagnosis was established by the demonstration of amastigote forms of Leishmania in Giemsa-stained bone marrow aspirates. Immunofluorescent antibody titers to Leishmania donovani (12) were higher than 1:512 in all patients. Patients with visceral leishmaniasis were treated with $N$-methylglucamine (Glucantime, [Rhodia SA, Sao Paulo, Brazil] SbV; $28 \mathrm{mg} / \mathrm{kg}$ per day) for a minimum of $10-14 \mathrm{~d}$. If the patient remained febrile and symptomatic, therapy with Glucantime was continued. None of the patients required $>30 \mathrm{~d}$ of treatment. Healthy hospital employees served as controls.

Mononuclear cell suspension. Mononuclear cells were obtained from heparinized peripheral blood by density gradient centrifugation using lymphocyte separating medium (Bionetics Laboratory Products, Kensington, MD) (13). The cells were washed twice, incubated at $37^{\circ} \mathrm{C}$ to elute surface proteins and washed again in RPMI 1640 (Gibco, Grand Island, NY). This cell suspension will be referred to as mononuclear cells.

Nonadherent lymphocyte preparation. To deplete the suspension of monocytes, $10 \times 10^{6}$ mononuclear cells were plated in $100 \times 15-\mathrm{mm}$ plastic Petri dishes (Falcon Labware, Oxnard, CA) at $37^{\circ} \mathrm{C}$ for $45 \mathrm{~min}$ in medium containing $10 \%$ FCS. The adherent cells were harvested and the procedure was repeated. This population will be referred to as nonadherent cells. It contained $2.0 \pm 0.7 \%$ esterase-positive cells. The initial mononuclear cell population had $28 \pm 3 \%$ esterase-positive cells.

In some experiments cells were passaged in nylon wool columns after the initial plating in Petri dishes (14). A 12-ml plastic syringe was packed with $0.6 \mathrm{~g}$ of nylon fibers (E. I. Dupont de Nemours \& Co., Inc., Wilmington, DE). After the column was rinsed with medium containing $5 \% \mathrm{FCS}$ and warmed to $37^{\circ} \mathrm{C}$, cells in medium containing FCS were applied to the column. The syringe was further incubated at $37^{\circ} \mathrm{C}$ for $45 \mathrm{~min}$. Nonadherent cells were eluted with RPMI. The percentage of $T$ cells in this population was $87 \% ; 1 \%$ were $B$ cells and $1 \%$ were monocytes. There were $66 \% \mathrm{~T}$ cells and $9 \% \mathrm{~B}$ cells before the depletion.

High-avidity $\mathrm{Fc}^{-}$lymphocyte population. To remove the cells with high-avidity Fc receptors for IgG, the mononuclear cells were allowed to attach to Petri dishes with immobilized BSA-anti-BSA immune complexes (15). To prepare these complexes, $2 \mathrm{ml}$ of BSA $(5 \mathrm{mg} / \mathrm{ml})$ in PBS was added to $60 \times 15-\mathrm{mm}$ Petri dishes for $45 \mathrm{~min}$ at $37^{\circ} \mathrm{C}$. After extensive washing with PBS, $2 \mathrm{ml}$ of IgG anti-BSA (1:20 dilution) (Cappel Laboratories, Cochranville, PA) was added to the dishes and incubated for $45 \mathrm{~min}$ at room temperature. The plates were washed five times with PBS and $8 \times 10^{6}$ cells in $2 \mathrm{ml}$ of medium were added. The plates were incubated for $1 \mathrm{~h}$ at room temperature and the nonadherent cells were recovered. This population will be referred as 
high-avidity $\mathrm{Fc}^{-}$lymphocytes. It also contained $1 \% \mathrm{Fc}^{+}$lymphocytes and $5 \%$ monocytes.

Depletion of $\mathrm{OKT}_{4}{ }^{+}$or $\mathrm{OKT}_{8}{ }^{+}$cells. To deplete T cells with the OKT 8 or OKT 4 marker, nonadherent cells were obtained by passage on Petri dishes and were adjusted to a concentration of $5 \times 10^{6} / \mathrm{ml}$. The cells were mixed with anti-OKT4 or anti-OKT8 monoclonal antibody (Ortho Diagnostic Systems Inc., Raritan, NJ) for $30 \mathrm{~min}$ on ice. After washing three times the cells were incubated with rabbit serum at a 1:20 dilution.

Separation of $T$ cells, freezing, and co-cultivation procedures. These studies were designed to determine if the normal blastogenic response of post-leishmaniasis treatment cells to Leishmania antigen would be diminished by cultivation with the unresponsive mononuclear cells obtained before treatment. $T$ cells were prepared from pretreatment mononuclear cells by isolating sheep erythrocyte rosette-forming cells by the procedure of West et al. (16). The only modification was that the sheep erythrocytes were not treated with neuraminidase. Briefly, 10 $\times 10^{6}$ lymphocytes in $1 \mathrm{ml}$ were mixed with $10 \times 10^{8}$ sheep erythrocytes in $4 \mathrm{ml}$ of RPMI and $2 \mathrm{ml}$ of FCS. After incubation for $1 \mathrm{~h}$ at $4^{\circ} \mathrm{C}$, $\mathrm{T}$ cells were separated by density gradient centrifugation and sheep erythrocytes were lysed with a hypotonic solution. Viability of the lymphocytes was over $95 \%$ after this procedure.

The freezing procedure was performed using the method of Birkeland (17). The lymphocyte pellet was resuspended in freezing medium containing 50\% RPMI, $40 \%$ human AB serum, and $10 \%$ DMSO. The cells $\left(2 \times 10^{6}\right.$ cells $\left./ \mathrm{ml}\right)$ were aliquoted in $1-\mathrm{ml}$ volumes into Nunc vials (Nunc, Intermed Co., Copenhagen, Denmark). The freezing procedure utilized a cryobiological freezing apparatus (biological freezer type BF-5, Union Carbide Corp., Indianapolis, IN). The freezing apparatus was started on the "E," and gradually lowered to "A," and maintained there overnight. The cells were then stored in liquid nitrogen at $-195^{\circ} \mathrm{C}$.

After periods of 1-3 mo the cell suspension was rapidly thawed by placing it in a $37^{\circ} \mathrm{C}$ water bath for $2-3 \mathrm{~min}$. The tubes were removed from the bath before the last ice on the tube melted. The suspension was immediately transferred to a centrifuge tube and $10 \mathrm{ml}$ of RPMI medium with $20 \% \mathrm{AB}$ serum was added slowly. The cells were washed twice and then centrifuged for $10 \mathrm{~min}$ at $1500 \mathrm{rpm}$ at room temperature before use. Trypan blue staining showed $>90 \%$ viable cells. The co-culture experiments were performed by culturing different numbers of these pretreatment cells $\left(5 \times 10^{3}\right.$ to $\left.5 \times 10^{4}\right)$ with $1 \times 10^{5}$ posttreatment mononuclear cells for $5 \mathrm{~d}$ in the presence of Leishmania antigen. In three healthy control subjects $\mathrm{T}$ cells were isolated from peripheral blood and frozen in the manner described above. The subjects were bled $1 \mathrm{wk}$ later and the previously frozen $T$ cells were added to the fresh mononuclear cells. In these experiments the cells were stimulated with Candida albicans antigen (final dilution of 1:40) and pokeweed mitogen (final dilution 1:100).

Lymphocyte blastogenesis assay. $2 \times 10^{5}$ cells in $0.2 \mathrm{ml}$ of RPMI 1640 , supplemented with antibiotics and $15 \%$ heat-inactivated human AB serum, were cultured in triplicate in flat bottom microtiter plates (Linbro Chemical Co., New Haven, CT) for blastogenesis assays. Cell cultures were incubated $\left(37^{\circ} \mathrm{C}, 5 \% \mathrm{CO}_{2}-95 \%\right.$ air) for $5 \mathrm{~d}$ with either Leishmania antigen in a concentration of $5 \mu \mathrm{g}$ of protein per $\mathrm{ml}$ of culture, purified protein derivative (PPD) $10 \mu \mathrm{g} / \mathrm{ml}$ of culture (Connaught Laboratories, Willow Dale, Ontario, Canada), C. albicans in a final dilution of $1: 40$, or PWM (Gibco) at a final concentration of $1: 100$. In three experiments, indomethacin in a final concentration of 1 $\mu \mathrm{g} / \mathrm{ml}$ was added with the Leishmania antigen. Blastogenesis was quantitated by liquid scintillation spectometry, after a $4.5-\mathrm{h}$ pulse of cell cultures with $1 \mu \mathrm{Ci}$ of $\left[{ }^{3} \mathrm{H}\right]$ thymidine $(6.7 \mathrm{Ci} / \mathrm{mM}$; New England Nuclear, Boston, MA). The results are expressed as the mean responses of $\left[{ }^{3} \mathrm{H}\right]$ thymidine incorporation in triplicate cultures.

Identification of mononuclear cells. The following procedures were used to determine the percentage of lymphocyte subpopulations and monocytes: $\mathrm{T}$ cells were characterized by their ability to bind sheep red

1. Abbreviations used in this paper: PPD, purified protein derivative. blood cells (18); B cells were identified by detecting surface immunoglobulin with fluoresceinated goat anti-human globulin (Hyland Laboratories, Deerfield, IL) (19); non-T, non-B high-avidity Fc receptor cells were identified by indirect immunofluorescence after exposure of the cells to normal human serum (19); OKT4 ${ }^{+}$and $\mathrm{OKT} 8^{+}$cells were quantitated after exposure of the cells to anti-OKT4 or anti-OKT8 monoclonal antibody followed by fluoresceinated anti-mouse IgG (20); and monocytes were identified by nonspecific esterase staining (21).

Delayed hypersensitivity skin testing. PPD (Connaught Laboratories, Swiftwater, PA) and C. albicans antigen (Hollister-Steir Laboratories, Spokane, WA) were utilized in $0.1-\mathrm{ml}$ volumes containing $5 \mathrm{TU}$ and 1:1,000 dilution, respectively. Responses were considered to be positive if there was $>10-\mathrm{mm}$ induration at $48 \mathrm{~h}$.

\section{Results}

The age, sex, and lymphocyte reactivity to Leishmania donovani chagasi, PPD, and $C$. albicans antigens, and PWM mitogen in 11 patients with visceral leishmaniasis are shown in Table I. In vitro responses to Leishmania antigen were either absent or minimal in all 11 patients. The responsiveness of patient's cells was not enhanced by stimulation with different concentrations of Leishmania antigen $(1.5,5$, and $25 \mu \mathrm{g}$ of Leishmania antigen). Mononuclear cells cultured with antigen for periods of 3,5 , and $7 \mathrm{~d}$ were equally unresponsive (Table I footnote). Eight of the 11 patients responded $(\geq 2,000 \mathrm{cpm})$ to either PPD, candida, or both antigens. All patients responded to PWM.

In an attempt to restore the lymphocyte blastogenesis to Leishmania antigen, mononuclear cells obtained from three patients with acute visceral leishmaniasis were depleted of monocytes and selected lymphocyte populations and $\left[{ }^{3} \mathrm{H}\right]-$ thymidine uptake was quantitated before and after these manipulations (Table II). To determine the role of adherent cells in suppressing the lymphocyte response to Leishmania anti-

Table I. Lymphocyte Blastogenesis to Leishmania, PPD, and C. albicans Antigens and to PWM in Patients with Visceral Leishmaniasis

\begin{tabular}{ccccc}
\hline $\begin{array}{c}\text { Patients' } \\
\text { age/sex }\end{array}$ & $\begin{array}{c}\text { Leishmania } \\
(5 \mu \mathrm{m} / \mathrm{ml})^{*}\end{array}$ & $\begin{array}{c}\text { PPD } \\
(10 \mu \mathrm{g} / \mathrm{ml})\end{array}$ & $\begin{array}{c}\text { C. albicans } \\
(1: 100)\end{array}$ & $\begin{array}{c}\text { PWM } \\
(1: 100)\end{array}$ \\
\hline$y r$ & \multicolumn{4}{c}{$\mathrm{cpm}$} \\
1/M & $855 \pm 70$ & $530 \pm 64$ & $2,023 \pm 299$ & $24,978 \pm 806$ \\
$6 / \mathrm{M}$ & $422 \pm 93$ & $315 \pm 72$ & $944 \pm 230$ & $10,430 \pm 701$ \\
$9 / \mathrm{M}$ & $544 \pm 29$ & $9,765 \pm 146$ & $612 \pm 71$ & $10,306 \pm 908$ \\
$14 / \mathrm{M}$ & $153 \pm 16$ & $10,889 \pm 570$ & $425 \pm 166$ & $13,869 \pm 1,230$ \\
$15 / \mathrm{F}$ & $138 \pm 29$ & $254 \pm 24$ & $244 \pm 31$ & $28,715 \pm 9,725$ \\
$15 / \mathrm{F}$ & $1,425 \pm 250$ & $1,553 \pm 514$ & $2,041 \pm 441$ & $33,158 \pm 1,184$ \\
$17 / \mathrm{M}$ & $453 \pm 82$ & $719 \pm 65$ & $2,326 \pm 310$ & $33,158 \pm 2,212$ \\
$19 / \mathrm{M}$ & $561 \pm 96$ & $17,321 \pm 887$ & $30,016 \pm 4,847$ & $17,046 \pm 1,136$ \\
$22 / \mathrm{M}$ & $1,583 \pm 11$ & $3,016 \pm 368$ & $4,511 \pm 1,021$ & $17,186 \pm 124$ \\
$24 / \mathrm{M}$ & $2,567 \pm 477$ & $1,290 \pm 110$ & $1,631 \pm 195$ & $5,829 \pm 100$ \\
$67 / \mathrm{M}$ & $302 \pm 34$ & $11,072 \pm 996$ & $4,416 \pm 767$ & $8,989 \pm 529$ \\
& & & &
\end{tabular}

Data represent mean $\pm \mathrm{SE}$ of $\left[{ }^{3} \mathrm{H}\right]$ thymidine incorporation. Background responses (cells without stimulation) were $467 \pm 107 \mathrm{cpm}$. * In four experiments dose-response curves using 1.5, 5, and $25 \mu \mathrm{g}$ of Leishmania antigen yielded $438 \pm 140,442 \pm 101$, and $285 \pm 56 \mathrm{cpm}$ $\times 10^{-3}$ after $5 \mathrm{~d}$ of in vitro cultivation. The mean response of cells from three patients with acute disease cultured for 3,5 , and $7 \mathrm{~d}$ with Leishmania antigen $(1 \mu \mathrm{g} / \mathrm{ml})$ was $472 \pm 134,571 \pm 192$, and $324 \pm 63$ $\mathrm{cpm} \times 10^{-3}$, respectively. 
Table II. Procedures Used to Attempt Restoration of Lymphocyte Reactivity to Leishmania Antigen in Patients with Acute Visceral Leishmaniasis

\begin{tabular}{lcc}
\hline \multicolumn{1}{c}{ Treatment } & Uptake & $\begin{array}{c}\text { Percentage of target cells before } \\
\text { and after depletion }\end{array}$ \\
\hline & $c p m$ & \\
None & $490 \pm 244^{*}$ & $28(\mathrm{M})$ \\
Plastic adherence & $427 \pm 223$ & $2(\mathrm{M})$ \\
None & $541 \pm 229$ & $25(\mathrm{M}, \mathrm{B}$ cells) \\
Nylon wool & $406 \pm 68$ & 1 (M, B cells) \\
None & $378 \pm 104$ & 12 (non-T, non-B, Fc ${ }^{+}$cells) \\
BSA-anti-BSA complex & $803 \pm 310$ & 1 (non-T, non-B, Fc ${ }^{+}$cells) \\
None & $390 \pm 89$ & 23 OKT8 ${ }^{+}$cells \\
Anti-OKT8 & $608 \pm 407$ & $<1$ OKT8 ${ }^{+}$cells \\
None & $1,271 \pm 769$ & 42 OKT4 ${ }^{+}$cells \\
Anti-OKT4 & $109 \pm 28$ & 3 OKT4 ${ }^{+}$cells \\
\hline
\end{tabular}

Data for each depletion method represents the mean \pm SEM for three patients.

* Data represents $\left[{ }^{3} \mathrm{H}\right]$ thymidine uptake of cultures stimulated with Leishmania antigen.

gen, these cells were removed from the mononuclear cell preparations by either plating the cells in Petri dishes or passing the cells through nylon wool columns. The percentage of macrophages, as determined by nonspecific esterase staining, was $28 \pm 3 \%$ before plating in Petri dishes and was $2 \pm 1 \%$ after depletion. Passage of the cells in nylon wool columns similarly reduced the percentage of macrophages from $25 \%$ to $1 \%$. Depletion of adherent cells by either method did not restore the response of the remaining mononuclear cells to Leishmania antigen. Before passage in Petri dishes the $\left[{ }^{3} \mathrm{H}\right]$ thymidine uptake of lymphocytes cultured with Leishmania antigen was $490 \pm 244 \mathrm{cpm}$, and after depletion it was $427 \pm 223 \mathrm{cpm}$. $\left[{ }^{3} \mathrm{H}\right]-$ Thymidine uptake before the depletion by nylon wool adherence was $541 \pm 229 \mathrm{cpm}$, and after depletion was $406 \pm 68 \mathrm{cpm}$. The reduced number of macrophages in the culture was not the explanation for the absence of response since $\left[{ }^{3} \mathrm{H}\right]$ thymidine uptake after either $C$. albicans or PWM stimulation was preserved after depletion of adherent cells by both procedures. For example, in one experiment the in vitro response after $5 \mathrm{~d}$ cultivation with $C$. albicans antigen was $8,115 \pm 23$ cpm after monocyte depletion and was $10,645 \pm 807 \mathrm{cpm}$ before depletion. To extend the studies of the potential role of macrophages in suppressing lymphocyte proliferation, indomethacin was added to cultures of mononuclear cells stimulated with Leishmania antigen. Indomethacin did not restore the response to Leishmania antigen: $\left[{ }^{3} \mathrm{H}\right]$ thymidine uptake was $372 \pm 21 \mathrm{cpm}$ (data not shown).

To determine the role of non-T, non-B, Fc receptor-positive cells in the suppression of lymphocyte reactivity, mononuclear cells from three patients were plated on a monolayer of BSA-anti-BSA immune complexes. This procedure depletes the high-avidity Fc receptor-positive cells (14). We reduced the number of $\mathrm{Fc}^{+}$cells from $12 \%$ to $1 \%$ by this method (Table II). After the passage in plates containing the BSA-anti-BSA complexes, the mononuclear cell preparations contained $76 \% \mathrm{~T}$ cells, $13 \% \mathrm{~B}$ cells, and $5 \%$ monocytes. Depletion of $\mathrm{Fc}^{+}$receptor cells did not restore the response to Leishmania antigen. $\left[{ }^{3} \mathrm{H}\right]$ Thymidine uptake of cultures stimulated with Leish- mania antigen before passage on BSA-anti-BSA was $378 \pm 104$ $\mathrm{cpm}$ and after depletion of $\mathrm{Fc}^{+}$cells was $803 \pm 310 \mathrm{cpm}$.

To determine if depletion of $\mathrm{OKT}^{+}$or $\mathrm{OKT} 8^{+}$cells could revert lymphocyte blastogenesis to Leishmania antigen, mononuclear cells were treated with either anti-OKT8 or antiOKT4 monoclonal antibody and complement. Treatment with anti-OKT8 plus complement reduced the percentage of $\mathrm{OKT}^{+}$cells from $23 \pm 3 \%$ to $<1 \%$ (Table II). Depletion of $\mathrm{OKT}^{+}$cells did not restore lymphocyte reactivity to Leishmania antigen. $\left[{ }^{3} \mathrm{H}\right]$ Thymidine uptake before $\mathrm{OKT} 8^{+}$cell lysis was $390 \pm 89 \mathrm{cpm}$, and after lysis it was $608 \pm 407 \mathrm{cpm}$. Depletion of $\mathrm{OKT}^{+}$cells also failed to restore lymphocyte blastogenesis to Leishmania antigen. Before OKT4 ${ }^{+}$cell depletion the $\left[{ }^{3} \mathrm{H}\right]$ thymidine uptake was $1,271 \pm 769$ and after depletion it was $109 \pm 28$.

Since lymphocytes from visceral leishmaniasis patients do not produce interleukin 2 (IL-2) when stimulated by Leishmania antigen, purified IL-2 (Genzyme Corporation, Boston, $\mathrm{MA}$ ) in concentrations ranging from 10 to $1,000 \mathrm{U} / \mathrm{ml}$ was added to mononuclear cells stimulated with Leishmania antigen. $\left[{ }^{3} \mathrm{H}\right]$ Thymidine uptake of cultures containing only media was $149 \pm 51 \mathrm{cpm}$, in cultures containing only IL-2 it was $2,619 \pm 1,869$, and in cultures containing antigen and IL-2 it was $1,995 \pm 1,318$. Healthy subjects' mononuclear cells cultivated with media alone or in media containing IL-2 yielded $200 \pm 58$ and $4,566 \pm 3,175 \mathrm{cpm}$, respectively.

$T$ cell subpopulations in visceral leishmaniasis. The numbers of $\mathrm{OKT}_{4}^{+}$and $\mathrm{OKT}^{+}$cells per cubic millimeter of peripheral blood was determined in 10 visceral leishmaniasis patients (Table III). Decreased numbers of helper cells were found in four patients. There was a marked lymphopenia $\left(<700 \mathrm{~mm}^{3}\right)$ in two patients. There was also a reduction in the number of $\mathrm{OKT} 8^{+}$cells in all but one of the patients with decreased OKT4 cell numbers. The OKT4 ${ }^{+} / \mathrm{OKT}^{+}$ratio of the whole group was $1.6 \pm 0.7$, which is not different $(P>0.05)$ from the ratio determined in healthy subjects in Brazil $(2: 2 \pm 0.7)$. All 10 patients were unresponsive to Leishmania antigens irrespective of whether they had normal numbers of $\mathrm{OKT}_{4}{ }^{+}$and $\mathrm{OKT} 8^{+}$cells.

The role of cells in the immunosuppression to antigen. Restoration of the lymphocyte reactivity to Leishmania antigen is associated with successful treatment of visceral leishmaniasis

Table III. Number of Lymphocytes and $\mathrm{OKT}^{+}$and $\mathrm{OKT8^{+ }}$ Cells in Peripheral Blood of Visceral Leishmaniasis Patients*

\begin{tabular}{crrrr}
\hline Age/sex & Lymphocytes & OKT4 $^{+}$ & OKT8 $^{+}$ & OKT4/OKT8 ratio \\
\hline$y r$ & & ${\text { No. } / m^{*}}^{*}$ & & \\
2/F & 2,015 & 544 & 604 & 0.9 \\
$2 / \mathrm{M}$ & 2,400 & 744 & 504 & 1.5 \\
$3 / \mathrm{F}$ & 3,796 & 1,746 & 1,100 & 1.6 \\
$6 / \mathrm{M}$ & 1,584 & 997 & 427 & 2.3 \\
$17 / \mathrm{M}$ & 2,200 & 888 & 289 & 3.0 \\
$17 / \mathrm{M}$ & 414 & 128 & 87 & 1.5 \\
$19 / \mathrm{M}$ & 1,760 & 458 & 492 & 0.9 \\
$21 / \mathrm{M}$ & 2,800 & 1,372 & 672 & 2.0 \\
$21 / \mathrm{M}$ & 832 & 258 & 242 & 1.0 \\
$38 / \mathrm{M}$ & 620 & 130 & 92 & 1.4 \\
\hline
\end{tabular}

* The expected absolute number of OKT4+ cells ranges from 468 to 1,143 and expected number of $\mathrm{OKT} 8^{+}$cells ranges from 192 to 726 . ‡ Value given as no./ml of peripheral blood. 
Table IV. Immunosuppression in Visceral Leishmaniasis: Evidence for the Role of T Cells

\begin{tabular}{lcc}
\hline \multicolumn{1}{c}{ Cell source } & \multicolumn{2}{c}{$\left[^{3} \mathrm{H}\right]$ Thymidine uptake* } \\
\cline { 2 - 3 } & Leishmania antigen & PWM \\
\hline & \multicolumn{2}{c}{$c p m \times 10^{3}$} \\
$\begin{array}{l}\text { Mononuclear cells before antimony } \\
\text { therapy }\end{array}$ & $460 \pm 76$ & $11,346 \pm 8$ \\
$\begin{array}{l}\text { Mononuclear cells 1-3 mo after } \\
\text { antimony therapy }\end{array}$ & $4,293 \pm 1,442$ & $-8,072 \pm 5$ \\
$\begin{array}{l}\text { Co-cultivation of pre- and post therapy } \\
\text { cells }\end{array}$ & $530 \pm 149$ & $5,917 \pm 5$ \\
\hline
\end{tabular}

* Results shown are the mean \pm SEM of studies of four patients. ${ }^{\ddagger}$ Mononuclear cell obtained after treatment $\left(1 \times 10^{5}\right)$ were co-cultured with $5 \times 10^{4}$ previously frozen pretreatment $T$ cells from the same patient for $5 \mathrm{~d}$ in the presence of antigen or mitogen.

(6). To further evaluate the role of cells in suppressing lymphocyte reactivity, co-culture experiments were performed using mononuclear cells from cured patients and cells from the same patients obtained before treatment. Pre- and posttreatment cells from four patients were studied in this manner. Table IV shows that cells obtained during the acute disease were able to suppress blastogenesis of autologous lymphocytes obtained after successful treatment. In these experiments the addition of $5 \times 10^{4}$ cells obtained during active disease decreased the response of the posttreatment mononuclear cells to Leishmania antigen from 4,293 $\pm 1,442 \mathrm{cpm}$ to $509 \pm 149 \mathrm{cpm}$, an $88 \%$ reduction. Co-cultivation of pre- and posttreatment cells did not significantly reduced the PWM response of the posttreatment cells $(8,072 \pm 592 \mathrm{cpm}$ to $5,917 \pm 571 \mathrm{cpm})(P$ $>0.05$ )

Fig. 1 shows that the cell-mediated suppression was dose dependent. In a representative experiment the $\left[{ }^{3} \mathrm{H}\right]$ thymidine uptake of mononuclear cells obtained after treatment was $7,618 \pm 1,027 \mathrm{cpm}$ after Leishmania antigen exposure. When 5 $\times 10^{3}$ pretreatment cells were cultured with $1 \times 10^{5}$ mononuclear cells the ${ }^{3} \mathrm{H}$ incorporation was decreased to $2,360 \pm 70$ cpm (69\% reduction). When $5 \times 10^{4}$ pretreatment cells were added the uptake decreased to $672 \pm 350 \mathrm{cpm}$ ( $91 \%$ reduction). Surface markers in the erythrocyte rosette-forming cell population after the freezing procedure showed that $64 \%$ reacted with anti-OKT 11 and that $7 \%$ of these cells were esterase positive.

To determine if a nonspecific effect of the freezing technique could account for the depression of lymphocyte reactivity to antigens, three healthy subjects with good lymphocyte reactivity to $C$. albicans were studied. These subjects had their cells frozen and after $1 \mathrm{wk}$ they were co-cultured with fresh cells and stimulated by $C$. albicans antigen. The $\left[{ }^{3} \mathrm{H}\right]-$

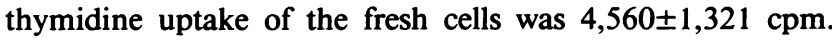
Co-culture of $1 \times 10^{5}$ fresh mononuclear cells with previously $\left(5 \times 10^{4}\right)$ frozen $T$ cells did not suppress the lymphocyte responsiveness $(4,609 \pm 1,848 \mathrm{cpm})$. Autologous responsive posttreatment cells were also frozen and then co-cultured with fresh autologous responsive mononuclear cells. In this experiment, $\left[{ }^{3} \mathrm{H}\right]$ thymidine uptake of fresh cells cultured with Leishmania antigen was $17,971 \pm 845 \mathrm{cpm}$. Co-culture of 1 $\times 10^{5}$ fresh autologous cells with previously frozen autologous cells $\left(5 \times 10^{4}\right)$ yielded $16,174 \pm 1,336 \mathrm{cpm}$ after $5 \mathrm{~d}$ of in vitro

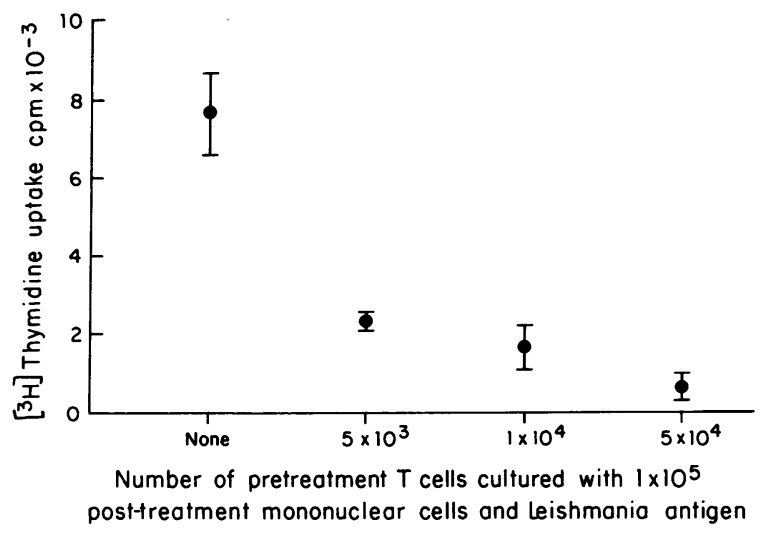

Figure 1. Leishmania antigen-specific cell-mediated immunosuppression.

cultivation. Control cultures with mononuclear cells cultured with autologous previously frozen cells in the absence of Leishmania antigen yielded $1,098 \pm 70 \mathrm{cpm}$.

\section{Discussion}

The present study documents that immunosuppression in visceral leishmaniasis is antigen specific and is cell mediated. Mononuclear cells from acute visceral leishmaniasis patients had a specific inability to respond to Leishmania antigen but most were able to proliferate when stimulated with either PPD or $C$. albicans. Studies testing delayed-type hypersensitivity reactions in leishmaniasis patients also have shown a lack of response to Leishmania antigen $(1,22)$.

The precise mechanisms of immunosuppression in visceral leishmaniasis are unknown. A decrease in the number of peripheral blood $\mathrm{T}$ cells is observed in one-fourth of patients (3). A decrease in $\mathrm{OKT}_{4}^{+}$is also seen in some patients. Antigenreactive cells trapped in lymphoid tissues may account for these observations and contribute to the lack of response to Leishmania antigen by peripheral blood cells. However, the lack of lymphocytes in T-dependent areas of lymph nodes and the spleen does not favor this view point $(23,24)$. Furthermore, although there is an absence of IL- 2 production by peripheral blood cells from patients with acute leishmaniasis (7), the addition of this lymphokine to the lymphocytes does not restore their responsiveness (11).

In co-culture experiments we were able to show that mononuclear cells obtained prior to the patients' antimony treatment suppressed the lymphocyte blastogenesis of cells obtained from the same patient after successful therapy. Mononuclear cells from healthy subjects did not suppress the lymphocyte response to PWM and $C$. albicans after the same freezing procedure used for the visceral leishmaniasis patients' cells. Furthermore, pretreatment cells from visceral leishmaniasis patients with active disease did not suppress the response of their posttreatment cells to either PWM or to C. albicans.

Attempts to restore responsiveness to Leishmania antigen in mononuclear cell preparations from patients with acute leishmaniasis were uniformly unsuccessful. Decreasing macrophage numbers by passage in Petri dishes or on nylon wool column did not restore the lymphocyte response. The addition of indomethacin also had no effect on $\left[{ }^{3} \mathrm{H}\right]$ thymidine uptake after stimulation with Leishmania antigen. Similarly, lymphocyte responsiveness was not restored by attempts to deplete the mononuclear cell preparations of either $\mathrm{Fc}^{+}$cells, $\mathrm{OKT} 4^{+}$, 
or $\mathrm{OKT}^{+}$cells. Sacks et al also were unable to reverse the specific unresponsiveness of mononuclear cells from patients with acute leishmaniasis by depletion of Leu- $2^{+}\left(\mathrm{OKT} 8^{+}\right) \mathrm{T}$ cells (11). Each of the different cell types has been shown to have suppressor effects in different patient populations and systems. Macrophages have been reported to mediate suppression of lymphocyte blastogenesis in diffuse cutaneous leishmaniasis $(25,26)$ and in tuberculosis (27). Cell lines with the T8 phenotype isolated from borderline leprosy patients are capable of suppressing blastogenesis to leprosy antigen (28). $\mathrm{Fc}^{+}$cells are able to suppress lymphocyte blastogenesis in the presence of immune complexes (29).

The inability to restore Leishmania antigen responsiveness to cells obtained during acute disease by depletion of lymphocyte subpopulations is in apparent conflict with the co-cultivation experiments indicating that a suppressor cell is present during acute disease. There are several potential explanations for these findings: (a) The targeted subpopulations were markedly decreased but not totally depleted-the few cells remaining may have been sufficient to exert a suppressive effect, $(b)$ The suppressive effect on the potential responder cells may not be reversed by removal of the suppressor cell, and $(c)$ The suppressor cell may have a phenotype other than those targeted for in the depletion experiments.

\section{Acknowledgments}

We are grateful to Drs. Thomas Jones and Heonir Rocha for their support, to Dr. Steve Reed for his critical review and comments, and to Ms. Betty Gittens for preparation of the manuscript.

This work was supported by grant AI-16282 from the National Institute of Allergy and Infectious Diseases and by the UNDP/World Bank/World Health Organization Special Program for Research and Training in Tropical Diseases and by the Brazilian Research Council (CNPq).

\section{References}

1. Andrade, T. M., R. Teixeira, J. A. F. Andrade, C. Pereira, and E. M. Carvalho. 1982. Hipersensibilidade do tipo retardado na leishmaniose visceral. Rev. Inst. Med. Trop. Sao Paulo. 24:298-302.

2. Manson-Bahr, P. E. C. 1961. Immunity in Kala-azar. Trans. $R$. Soc. Trop. Med. Hyg. 55:550-555.

3. Carvalho, E. M., R. S. Teixeira, and W. D. Johnson, Jr. 1981. Cell mediated immunity in American visceral leishmaniasis: reversible immunosuppression during acute infection. Infect. Immun. 33:498502.

4. Carvalho, E. M., and R. S. Bacellar. 1983. Lymphocyte reactivity to mitogens in American visceral leishmaniasis. Braz. J. Med. Biol. Res. 16:35-41.

5. Haldar, J. P., S. Chose, K. C. Saha, and A. C. Ghose. 1983. Cell-mediated immune response in Indian kala-azar and post Kalaazar dermal leishmaniasis. Infect. Immun. 42:702-707.

6. Ho, M., D. K. Koech, D. W. Iha, and A. D. M. Bryceson. 1983. Immunosuppression in Kenya visceral leishmaniasis. Clin. Exp. Immunol. 51:207-214.

7. Carvalho, E. M., R. Badaro, S. G. Reed, T. C. Jones, and W. D. Johnson, Jr. 1985. Absence of gamma interferon and interleukin 2 production during active visceral leishmaniasis. J. Clin. Invest. 76:2066-2069.

8. Barral, A., E. M. Carvalho, R. Badaro, and M. Barral-Netto. 1986. Suppression of lymphocyte proliferative responses by sera from patients with American visceral leishmaniasis. Am. J. Trop. Med. Hyg. 35:735-742.

9. Rezai, J. R., S. M. Ardehali, G. Amirhakimi, and A. Kharazmi.
1978. Immunological features of kala-azar. Am. J. Trop. Med. Hyg. 27:1079-1083.

10. Musumeci, S., G. Schiliro, S. Li Volti, and A. Sciotto. 1980. Lymphocyte changes in Mediterranean Kala-azar. Trans. R. Soc. Trop. Med. Hyg. 75:304-305.

11. Sacks, D. L., S. Lata Lal, S. N. Shrivastava, J. Blackwell, and F. A. Neva. 1987. An analysis of T cell responsiveness in Indian Kalaazar. J. Immunol. 138:908-913.

12. Badaro, R., S. G. Reed, and E. M. Carvalho. 1983. Immunofluorescent antibody test in American visceral leishmaniasis: sensitivity and specificity of different morphological forms of two Leishmania species. Am. J. Trop. Med. Hyg. 32:480-484.

13. Horwitz, D. A., and M. A. Garrett. 1977. Distinctive functional properties of human blood $\mathrm{L}$ lymphocytes: a comparison with $\mathrm{T}$ lymphocytes, B lymphocytes, and monocytes. J. Immunol. 118:17121721.

14. Trizio, D., and G. Cudkowicz. 1974. Separation of T and B lymphocytes by nylon wool columns: evaluation of efficacy by functional assays in vivo. J. Immunol. 113:1093-1097.

15. Carvalho, E. M., J. S. Davis, and D. A. Horwitz. 1980. Conditions required for Fc-dependent immune complex enhancement of antigen-specific lymphocyte blastogenesis. J. Immunol. 124:565-570.

16. West, W. H., S. M. Payne, J. L. Weese, and S. R. B. Herverman. 1977. Human T lymphocytes subpopulations: correlation between Erosette-forming affinity and expression of Fc receptor. J. Immunol. 119:548-554.

17. Birkeland, J. A. 1980. Cryo preservation of human lymphocytes for sequential testing of immune competence. J. Immunol. Methods. 35:57-67.

18. World Health Organization IARC Workshop. 1974. Special technical report. Identification, enumeration and isolation of $B$ and $T$ lymphocytes from human peripheral blood. Scand. J. Immunol. 3:521-532.

19. Lobo, P. I., and D. A. Horwitz. 1976. An appraisal of Fc receptors on human peripheral blood B and L lymphocytes. J. Immunol. 117:939-943.

20. Reinherz, E. L., P. C. Kung, G. Goldstein, and S. F. Schlossman. 1979. Separation of functional subsets of human $\mathrm{T}$ cells by a monoclonal antibody. Proc. Natl. Acad. Sci. USA. 76:4061-4065.

21. Li, C. Y., K. W. Lam, and L. T. Yam. 1971. Esterases in human lymphocytes. J. Histochem. Cytochem. 21:1-12.

22. Hopner, E., and E. Mendes. 1981. Impaired cell-mediated immunity in patients with Kala-azar. Allergol. Immunol Pathol. 9:109112.

23. Veress, B., A. Omer, A. A. Satir, and A. M. El Hassan. 1977. Morphology of the spleen and lymph nodes in fatal visceral leishmaniasis. Immunology 33:605-610.

24. Carvalho, E. M., A. D'Olivera, and A. C. Queinoz. 1985. Imunopatologio lojes do baco na leishmaniose visceral. Rev. Soc. Bras. Med. Trop. 18:109-112.

25. Petersen, E. A., F. A. Neva, C. N. Oster and H. Bogaert. 1982. Specific inhibition of lymphocyte proliferation responses by adherent suppressor cells in diffuse cutaneous leishmaniasis. N. Engl. J. Med. 306:387-390.

26. Petersen, E. A., F. A. Neva, A. Barral, R. Correa Coronas, H. Bogaert-Diaz, D. Martinez, and F. E. Ward. 1984. Monocyte suppression of antigen-specific lymphocyte responses in diffuse cutaneous leishmaniasis patients from the Dominican Republic. J. Immunol. 132:2603-2606.

27. Ellner, J. J. 1978. Suppressor adherent cells in human tuberculosis. J. Immunol. 121:2573-2579.

28. Ottenhoff, J. M., P. G. Elfering, P. R. Kloster, and R. P. Uries. 1986. Cloned suppressor $\mathrm{T}$ cells from a lepromatous leprosy patient supress Mycobacterium leprae reactive helper T cells. Nature (Lond.). 322:462-464.

29. Ryan, J. L., and P. A. Henkart. 1976. Fc receptor-mediated inhibition of B lymphocyte activation. J. Exp. Med. 144:768-775. 